\title{
Internal Audit Practices and Financial Management Reforms: The Case of Payroll Accounting System in the Tanzania Public Sector
}

\author{
Nuru Kalufya, Riziki M. Nyello \\ Institute of Social Work, Dar es Salaam, Tanzania \\ Email: nkalufya@gmail.com, rizikim6@gmail.com
}

How to cite this paper: Kalufya, N., \& Nyello, R. M. (2021). Internal Audit Practices and Financial Management Reforms: The Case of Payroll Accounting System in the Tanzania Public Sector. Open Journal of Business and Management, 9, 1064-1088. https://doi.org/10.4236/ojbm.2021.93057

Received: February 8, 2021

Accepted: May 10, 2021

Published: May 13, 2021

Copyright (อ 2021 by author(s) and Scientific Research Publishing Inc. This work is licensed under the Creative Commons Attribution International License (CC BY 4.0).

http://creativecommons.org/licenses/by/4.0/ (c) (i) Open Access

\begin{abstract}
Several initiatives as part of the public sector financial management reforms to improve the payroll system in Tanzania were introduced. Despite such initiatives, different cases of fraudulent were reported which raised the need for examining the influence of internal audit practices on the payroll accounting performance. The article involved 240 respondents from 321 public institutions. Stratified sampling technique and questionnaires were used as sampling technique and data collection instrument respectively while structural equation model (SEM) and Mean were used in data analysis. Focusing on the institutional theory and contingency theory, the results revealed that control environment had significantly positive influence on payroll record processing while risk-based internal audit had significantly positive influence on payroll reconciliation. Internal auditors' professional competence had significantly positive influence on payroll reconciliation, payroll record processing and payroll accounting system coverage. Furthermore, internal audit work performance had significantly positive influence on payroll reconciliation and payroll accounting system coverage. Among others, the article recommends that managers should consider internal audit function as a strategic function and not operational to strengthen the payroll accounting system.
\end{abstract}

\section{Keywords}

Internal Audit Practices, Payroll Accounting System and Public Sector

\section{Introduction}

Public service has been always the top option available to African governments 
for the implementation of developmental goals and objectives and, seen as been crucial to the growth and development of African economies (Fatile et al., 2010). Despite the importance of public services in economic development, there was a claim that the public sector poorly provides the public services and characterized by lack of transparency, lack of accountability and the misuse of public funds (Fiszbein, 2000; Adegoroye, 2008). In order to improve the public sector's performance, governments in Africa reformed the public sector (Doherty \& Home, 2002; Lufunyo, 2013).

The public sector reform is considered to be a set of processes and practices that are aimed at strengthening the management of the public sector (African Development Bank, 2005). Reforms are categorized into three groups, i.e. performance management systems, public sector restructuring, and financial management reforms (Therkildsen, 2000; Rugumyamheto, 2005). However, public financial management is absolutely critical to improving the quality of public service outcomes (CIMA, 2010). It affects how funding is used to address national and local priorities, the availability of resources for investment and cost effectiveness of public services (Cima, 2010). Lufunyo (2013) adds that the public sector financial management reform programmes intend to ensure an efficient use of resources in spite of the resource constraints.

There were several public sector financial management reforms conducted in Tanzania. These reforms include an empowerment public institution to have an authority to allocate the collected funds (Lufunyo, 2013) and the management of payroll system. However, the payroll management is considered to be the most crucial reform in the public sector and constitute more than $50 \%$ of recurrent costs in the developing countries including Tanzania (Dorotinsky \& Pradhan, 2007) while in the social sector, the figure can be as high as $90 \%$ (Diamond, 2002). Payroll management requires careful planning, budgeting execution and audit and, therefore it dominates the whole budgeting process. Then, there is a need for sound payroll controls to curb corrupt payments and the existence of ghost workers (Dorotinsky \& Pradhan, 2007). In ensuring effective payroll management in the public sector, most researchers (Van Gansberghe, 2005; Sage, 2011; Suryanto, 2011; Toakodi \& Assi, 2016) mainly focus on the automation of payroll management.

The automation of payroll management is considered to simplify work, necessitate security of data and effective management of payroll transactions (Toakodi \& Assi, 2016). In this vein, development of payroll and human resource database was the major supported initiative (Obara \& Nangih, 2017). It is likewise in Tanzania whereby the automation of payroll transactions was considered as the panacea of poor management of payroll transactions. However, the performance of payroll accounting system in the developing countries was contrary to the expectations. The failures of payroll accounting systems in many developing countries are well documented (Polidano, 2001). Tanzania was not the exceptional case, it experienced the same trajectory. Tanzania payroll system experienced a 
number of challenges including the existence of ghost workers and one employee having more than one check number. In 2016 the number of ghost workers and corrupt practices in the payroll accounting system were identified. It raises doubts on the performance of payroll accounting system in terms of payroll reconciliation, payroll record processing and payroll system coverage.

In looking for the solutions, there is a considerable debate on the most appropriate structure and functions on controlling the payroll system. Some researchers (like Diamond, 2002; Hepworth, 2004) argue that there is still a need for a centralized function with a continuing role in compliance and regularity. Others (such as Rameesh, 2003; Van Gansberghe, 2005) support for a more independent system-based audit. Despite such debate, the internal audit practices play a vital role in managing payroll transactions and monitoring the performance of payroll accounting system (Van Gansberghe, 2005; Rameesh, 2003). Internal audit is an overall monitoring and evaluating activity that focus on the effectiveness of control procedures which are the responsibility of other functional managers (Kiabel, 2012).

In addition, the internal audit has a role to assist the management to effectively perform their responsibilities by providing them with analysis, appraisal, recommendations, and pertinent comments concerning the reviewed activity (Okezie, 2004). The internal audit includes system audit, performance audit and compliance audit (Nwaobia, 2016). However, the proper functioning of internal audit in terms of performing system audit, performance audit and compliance audit may depend on the internal control environment, internal auditors' professional competences, risk management and internal audit work performance. Despite the potential role of internal audit practices, most researchers (such as Sage, 2011; Suryanto, 2011; Toakodi \& Assi, 2016) mainly focus on the introduction of payroll accounting system. There is limited focus on the performance of payroll accounting system in relation to internal audit practices. There is a dearth of knowledge on the influence of internal audit practices on the individual performance indicators of the payroll system i.e. payroll reconciliation, payroll record processing and payroll system coverage.

Furthermore, researchers (such as Kiabel, 2012) considered internal audit function as an accounting function (i.e. operational) and not the management oriented function (i.e. strategic). Due to the perception of internal audit as an accounting function, the prior empirical studies included narrow scope of respondents. For instance, Kiabel (2012) sampled chief accountants, chief internal auditors, finance managers and other accountants only and left behind human resource professionals. It is argued that internal audit function is the strategic function and not a mere accounting function (Hellman, 2011; Feizizadeh, 2012).

In addition, the reviewed empirical studies (such as Okezie, 2004; Kiabel, 2012; Toakodi \& Assi, 2016) mainly used descriptive statistics and regression analysis as data analysis techniques. The techniques cannot capture the multiple relationships simultaneously; hence, it is likely that other relationships have not 
been captured. Using other data analysis techniques such as structural equation modelling (SEM), it can be possible to test and identify other relationships among variable. Considering the mentioned limitations, this article examines the influence of internal audit practices on the performance of payroll accounting system. The article has six sections which consist of introduction, literature review, research methodology. Discussion of findings, conclusions, recommendations, limitations and areas for further studies. Introduction section among other things explains the research gaps which justify the need for conduction this research work. The literature review discusses theoretical and empirical literature review, and hypotheses to be tested.

\section{Theoretical Literature Review}

The institutional theory has gained more recognition in studying the Choice of accounting techniques and systems (Scott, 1987). This is because the choice of accounting techniques and systems is influenced by the institutional processes, structured and regulative processes (Scott, 1987). Then, the theory recognizes the fact that the self-interest maximizing behaviours by managers may not influence the choice of accounting techniques and systems but the institutional and social pressures and expectations (DiMaggio \& Powell, 1983; Scott, 1987; Oliver, 1997). Then, Carpenter and Feroz (2001) contend that "institutional theory is important in explaining accounting choice [and systems] in organizations where self-interest maximizing behaviour by managers cannot exert effective influence over the choice of accounting practices because of their relative power positions in their organizations" (p. 566). In this fact, the institutional environment cannot only have an influence on the choice of accounting and internal audit practices and systems but even the relationship among themselves particularly in the public sector.

The institutional theory recognises the influence of institutional environment, both formal and informal, on the choice of accounting techniques, methods and systems. The formal institutional environment includes the formal rules i.e. laws, regulations and standards while informal institutional environment mainly focuses on how the key actors conceptualise the environmental management and guidelines (Young, 1982). "Given the presence of formal institutional environment, it is likely that the public organizations may behave the same because managers may tend to adopt a particular accounting system or technique or method to seek for the institutional legitimacy. Hence, organizations become increasingly homogeneous within given domains and conform to wider institutional expectations" (Carpenter \& Ferox, 2001: p. 566).

With this fact, DiMaggio and Powell (1983) came up with the concept of isomorphic that explains how the organizations become homogeneous. They divided isomorphic into two categories i.e. competitive and institutional isomorphic. The competitive isomorphic mainly focuses on the open and free market competition while institutional isomorphic focuses on political power, social fit- 
ness and institutional legitimacy. DiMaggio and Powell (1983) then argue that competitive isomorphic cannot be applied in the public sector organizations because of its focus on open and free market. Hence, even this article opted for institutional isomorphic. Generally, basing on the institutional isomorphic, the theory considers the interaction between an organization and external environment, the social expectations and effects, organization characteristics and practices and, ability of the organization to accommodate the identified expectations (Martinez \& Dacin, 1999).

The article opted for the institutional theory because the influence of internal audit practices on the payroll accounting system performance may be influenced by the institutional and social pressures and expectations. Moreover, internal audit practices in the public sector organizations such as control environment and internal auditors' professional competences, are guided by a number of institutional regulatory requirements such as laws and rules. Moreover, the article argues that the influence of internal audit practice on the payroll accounting payroll system may depend on the interaction between the internal audit practices of the organization and the institutional environment such as rules, social expectation effects and organizational characteristics. Hence, the institutional theory was used to examine the influence of control environment and internal auditors' professional competence on the payroll accounting performance.

Moreover, the article opted for the contingency theory to examine the influence of risk-based internal audit and internal audit work performance on the payroll accounting performance. Risk-based internal audit and internal audit work performance are contextual factors that can adequately be explained by the contingency theory. The institutional theory does not recognize the uniqueness among the public sector organizations, despite the fact that they may belong in the same domain, in terms their practices rather it assumes that the organizations are homogeneous in terms of practices and the way they are formed. But risk-based internal audit and internal auditors' work performance practices may be different depending on the unique characteristics of the organization. Hence, their influence on the payroll accounting performance may be determined to the extent the mentioned internal audit practices fit with the payroll accounting system in a particular context.

Payroll accounting system is one of the public sector financial management reforms. The development and performance of payroll accounting system are determined by the context in which the system is expected to operate. This is supported by Nzuve and Njeru (2013) that public sector reforms must be based on the experiences of organizations within countries than one-size-first-all approaches that have become a norm. In addition, recognizing the importance of considering the contextual differences, Fatile (2012) and Agwanda (2019) contend that public sector reforms (such as payroll accounting system) must be indigenised to reflect the African contexts. Likewise, Awan and Khan (2016) opine that performance targets and controls of the information system must be 
in line with the organization objectives.

Hence, prior empirical studies advocate for the analysis of payroll accounting system performance from the contingency perspective. With this fact, the contingency theory has been used in this article to examine the influence of internal audit practices on the performance of payroll accounting system. The theory states that the context determines the best way for the institution to organise itself (Weill \& Olson, 1987). It is further contended that there must be a fit between individual personality (such as professional proficiency) and information system for the system to perform well (Kaiser \& Bostronn, 1982; Weiss, 1983). With this fact, the influence of internal audit practices on the performance of payroll accounting system depends on the extent they fit each other as determined by the organisation characteristics that some of them may be unique.

\section{Empirical Literature Review}

\section{Audit Control Environment and Payroll Accounting System}

The audit control environment plays a very important role as it is considered as a powerful brake on the possible deviations from the pre-determined objectives and policies (Kiabel, 2012). Control environment includes, but not limited to, management support, independence of the internal audit unit and infrastructural facilities. For instance, Nwaobia, Ogundajo and Niyonzima (2016) contend that full autonomy of internal audit unit and well equipped with infrastructural facilities are one of the control environmental factors. IIA (2012) argues that stakeholders' support and a formal mandate of internal audit unit are also audit control environmental factors that may be core to the better performance of payroll accounting system. Hence, the following hypothesis was developed: -

$H_{1}$ : Control environment positively influences the performance of payroll accounting system.

\section{Professional Competence and Payroll Accounting System}

Internal audit should be performed by auditors who possess qualified skills and knowledge. IIA (2012) opines that demands for objective and competent staff are important in the proper functioning of the control system. This is supported by other empirical studies (i.e. IIA, 2009; Selim, Woodward, \& Allegrini, 2009; IIA, 2009; Akinbuli, 2010) attest that internal auditors should use their professional skills, due care and prudence in every assignment including examining the performance of payroll accounting system. It is further argued that internal auditors' knowledge and experience of the operations of the organizations (Selim et al., 2009) and internal auditors' adequacy, quantity and competence (Akinbuli, 2010) determine the quality of internal auditors' report and opinion. Hence, the following hypothesis was developed:

$\mathrm{H}_{2}$ : Internal auditors professional competence positively influences the performance of payroll accounting system

Risk-Based Internal Audit and Payroll Accounting System Performance

Risk management is one of the main functions of internal auditors (Drogalas 
\& Siopi, 2017). Risk management is so important because it is associated with the performance of the organization (Selim et al., 2009) including payroll accounting system. Regardless of the types of internal audit, Arena and Azzona (2009) consider risk management as a process of identifying and analysing the management of relevant risks. In this vein, risk management is the role and responsibility of internal auditors (Aikins, 2011; Vijayakumbar \& Nagaraja, 2012) and may determine the performance of payroll accounting system. Hence, the following hypothesis was developed:

$H_{3}$ : Risk-based internal audit positively influences the performance of payroll accounting system.

Internal Audit Work Performance and Payroll Accounting System Performance

Internal audit work performance may influence the performance of payroll accounting system. Internal auditors' objectivity, awareness and ability to engage the stakeholders may be important in the internal auditing process. For instance, it is argued that internal auditors' objectivity and ability to engage the stakeholders influence the quality of internal auditors' opinion and report (IIA, 2009; Alzeban \& Gwilliam, 2012). IFAC (2010) contends that full awareness of organization operations determines the reliability of information to be reported by the internal auditors. It is further opined that internal auditors' objectivity enhances management quality and moderate audit risks (Cohen \& Sayag, 2010; Hellman, 2011). Hence, the following hypothesis was developed:

$\mathrm{H}_{4}$ : Internal audit work performance positively influences the payroll accounting system performance.

\section{Research Methods}

\section{Research Design}

The article applied the cross sectioned design to guide the research process. The design was chosen because the respondents were from different subgroups i.e. internal audit unit and finance department. Respondents from the mentioned subgroups were included because the internal audit function is not aimed for internal audit unit only. With this fact, the cross-sectional design was regarded as the best design in this article because respondents are categorized into two major subgroups. It is supported by Thisted (2006) who argues that cross sectional design allows the researcher to effectively control the accuracy of estimates in subgroups that are considered as the data sources.

\section{Population and Sampling Procedures and Design}

The article involved Organizations from the Public Sector which are Ministries, Agencies and Departments (MDAs), Local Government Authorities (LGAs) and Public Institutions. Specifically, there are 136 MDAs and 185 LGAs which makes a total of 321 Organizations in the Tanzania Public Sector. In this regard, the sample size of 178 was calculated using Taro, Yomane's formula in order to infer the results to the entire population. The formula is mathematically 
written as $S=N /\left(1+N(e)^{2}\right)$ whereby the population $(N)$ was 321 and the sampling error (e) of 0.05 . Specifically, the article intended to have $75 \mathrm{MDAs}$, and 103 LGAs. More clarifications are shown in the following mathematical calculation:

$$
\begin{aligned}
S & =N / 1++N(e)^{2} \\
& =321 / 1+321(0.05)^{2} \\
& =321 / 1+0.8025 \\
& =321 / 1.8025 \\
& =178
\end{aligned}
$$

With this fact, the article was expected to collect data from the respondents who were from the following categories: Finance Department and Internal Audit Unit. Hence, in each selected organization, a total of two (2) respondents were expected to be part of this article which make the expected total of 356 respondents. Actually, the article involved 119 respondents from 72 MDAs; 134 respondents from 84 LGAs which made a total of 253 respondents, who had the working experience of at least one year in the same organisation, from 156 organisations. Furthermore, the article adopted for the stratified sampling technique because the respondents were categorized into two strata.

\section{Research Instrument and its Administration}

The article used self-design questionnaire that was developed and reviewed by experts in the field. The questionnaire was reviewed by five (5) academicians in accounting field, six (6) human resource management experts and four (4) registered accountants and auditors. The experts gave out their opinions regarding an addition of risk-based internal audit and measurement items. It was thereafter distributed to a small group of 25 people working for public institutions in relevant positions to test whether or not the questionnaire was well-understood. The administration of such questionnaire to a small group of 25 respondents resulted to an increase of measurement items including accuracy of changes in payroll system, proof of qualifications of the employees and validity of new employees' appointment. In addition, the exploratory factor analysis was also conducted to explore items that explain the selected research variables and their items included in the questionnaire.

In this article, 312 questionnaires were distributed to the respondents in 156 public sector organisations and 253 questionnaires were collected. The questionnaire was divided into three sections whereby the first two sections covered organizational profile and demographic profile of the respondents and titled as section $A$ and $B$ respectively. Section $C$ of the questionnaire was designed to capture the internal audit practices and payroll accounting system performance and written in a 5-point Likert scale. The questionnaires were self-administered which largely reduced the possibility of outliers in the data meanwhile maintaining the "objectivity" intention for the quantitative study. 


\section{Data Profile}

Data were collected from finance staff and internal audit unit staff who were considered as respondents because the article argues that internal audit function is not for the internal audit department, but it involves even the staff from finance department. With this fact the contribution of the internal audit practices on payroll system performance can be influenced by the diversified internal stakeholders of the organization. Hence, data were collected from the finance staff (64.2\%) and internal auditors (35.8\%). Most of respondents (i.e. 95\%) had the working experience of at least two years however, $68 \%$ of the respondents had an experience of more than three (3) years in working with the organizations included in the sample. With this fact, the article involved respondents who had an experience of at least two (2) years in the same organisation because they were perceived to have adequate knowledge on the organisation. Hence, the article used data from 240 respondents who had the working experience of at least two years out of 253 respondents. In this case, the article did not use data from 13 respondents who had the working experience of one year in the same organisation that was studied.

\section{Data Analysis Techniques}

This article used Mean scores as the descriptive data analysis technique and covariance based-structural equation model (CB-SEM). Mean was used to rank variables in order to provide more descriptive information on the results obtained after testing the hypotheses using CB-SEM through Amos version 23. CB-SEM was used due to its ability to capture multiple relationship at the same time which makes possible to determine the contribution of each independent variable in the whole model.

\section{Reliability and Validity}

The exploratory factor analysis (EFA) was conducted in order to assess the factor loadings in a particular variable. EFA is also considered as a reliability test that looks at the extent to which a factor loads to a particular variable. After conducting EFA, seven variables were explored. These variables included internal auditors' professional competence; control environment; risk-based internal audit; performance of audit work; payroll reconciliation; payroll record processing and payroll accounting system coverage. The Kaiser Meyer Olkin (KMO) measure of sampling adequacy was 0.946 which was above the cutoff point of 0.5. The Bartlett Test of Sphericity was also significant at 0.001 . More details are shown in Appendix 1 and 2.

After conducting EFA, the Cronbach Alpha test was conducted to examine the internal consistency of items in each variable. It assesses whether the responses to the items do not differ to conclude that the items actually explain a specific variable (Kiabel, 2012). According to Nunnaly (1967), the Cronbach Alpha Coefficient must be at least 0.7 to claim that there is an internal consistency in a specific variable. The calculated Cronbach Alpha Coefficients were all above 0.70 hence the internal consistency in each variable was achieved as demonstrated by 


\section{Table 1.}

\section{Operationalization and Measurement of Variables}

The article had two main categories of variables i.e. independent variables and dependent variables. Independent variables include the internal audit practices which consist of four variables i.e. internal audit work performance, risk based internal audit, control environment and internal auditors' professional competences. The four internal audit practices were obtained from the prior empirical studies. Internal auditors' work performance has been mentioned by several prior empirical studies (such as Muchiri \& Jogongo, 2017; Mihret, James, \& Mula, 2010; Al-Shbail \& Turki, 2017). Risk based-internal audit has been mentioned by Mihret et al. (2010); and control environment has been mentioned by Carpenter and Feroz, (2001) and Mihret et al. (2010). The internal auditors' professional competence has been also mentioned by Hutchinson and Zain (2009), Al-Matari, Al-Swidi, and Fadzil (2013); Muchiri and Jogongo (2017) and Tsai, Chen, Chand, and Lee (2017).

Tsai et al. (2017) further explain issues that can be considered to evaluate the performance of a particular system. These issues include system quality, information quality, user satisfaction and impact. However, the system quality is a broad concept that can be determined by the information quality. In addition, user satisfaction and system impact may be determined by the information quality. With this fact, information quality may be determined by payroll reconciliation, payroll record processing and payroll accounting system coverage as the dependent variables in this article. The 5-point Likert scale was used to measure the internal audit practices as it was used by Kiabel (2012). The payroll accounting system performance was also measured in the 5 Point-Likert scale because the article wanted to capture the perceptions of respondents on payroll accounting performance.

\section{Research Results}

\section{Respondents' and Organizations' Profile}

Basing on educational level, 106 (44.2\%) had acquired the bachelor degree

Table 1. Cronbach alpha coefficients and number of items.

\begin{tabular}{ccc}
\hline Variable & Number of Items & Cronbach Alpha Coefficients \\
\hline Internal Auditors Professional & 11 & 0.96 \\
Competence & & \\
Control Environment & 10 & 0.935 \\
Risk based Internal Audit & 5 & 0.935 \\
Internal Audit work performance & 5 & 0.809 \\
Payroll reconciliation & 10 & 0.973 \\
Payroll record processing & 6 & 0.702 \\
Payroll accounting system coverage & 6 & 0.944
\end{tabular}


while 134 (55.8\%) had the postgraduate degrees. It was further revealed that 79 (32.9\%) respondents were involved in the preparation of payroll accounting system while 161 (67.1\%) respondents were not involved. Furthermore, 114 (47\%) respondents were involved in the internal audit process while 126 (53\%) respondents were not involved in the internal audit. This shows that the preparation of payroll accounting system mainly involved human resource professionals and administrators. Likewise, the internal auditors were mainly involved in auditing. Table 2 presents the summarised information.

Basing on organizational profile, 4 (1.7\%) organisation employed between 50 to 100 employees; 9 (3.8\%) organizations employed between 101 to 250 employees; and $62(25.8 \%)$ organisations employed between 251 to 500 employees. Furthermore, 118 (49.2\%) employed between 501 to 1000 employees while 47 (19.6\%) organisations employed more than 1000 employees. In addition, all organisations had computerized their payroll transactions while 54\% used manual payroll accounting system to casual and part-time employees.

\section{Internal Audit Practices and Payroll Accounting System Performance Descriptive Results}

According to Oxford and Burry-stock (1995), the Mean score that ranges between 1 and 2.4 indicates the low influence, 2.5 to 3.4 indicates the medium influence while 3.5 to 5 indicates the high influence assuming the Likert scale of 5 . The descriptive results revealed that there was a high focus on auditors' professional competence (Mean $=4.3063$ ); improving the control environment (Mean $=4.3207)$; risk-based internal audit $($ Mean $=4.3437)$ and internal audit work performance $($ Mean $=4.2697)$. This implies that the internal audit practices highly focused on the four mentioned issues because the Mean scores in all variables that measured the internal audit practices were more than 3.5. Based on payroll accounting system performance, the descriptive results showed the high focus on payroll reconciliation (Mean $=4.2870$ ); payroll record processing $($ Mean $=4.2381)$ and payroll accounting system coverage $($ Mean $=4.3375)$. Table 3 presents the summarized information.

Table 2. Respondents' profile.

\begin{tabular}{|c|c|c|c|}
\hline Category & Details & Frequency & Percent \\
\hline \multirow{3}{*}{ Educational level } & Postgraduate qualification & 134 & 55.8 \\
\hline & Bachelor degree & 106 & 44.2 \\
\hline & Total & 240 & 100 \\
\hline \multirow{3}{*}{$\begin{array}{l}\text { Involvement in the } \\
\text { preparation of payroll system }\end{array}$} & Yes & 79 & 32.9 \\
\hline & No & 161 & 67.1 \\
\hline & Total & 240 & 100 \\
\hline \multirow{3}{*}{$\begin{array}{l}\text { Involvement in the internal } \\
\text { auditing process }\end{array}$} & Yes & 114 & 47 \\
\hline & No & 126 & 53 \\
\hline & Total & 240 & 100 \\
\hline
\end{tabular}


Table 3. Descriptive results.

\begin{tabular}{cc}
\hline Research Variable & Mean Score \\
\hline Auditors' professional competence & 4.3063 \\
Control environment & 4.3207 \\
Risk-based internal audit & 4.3437 \\
Internal audit work performance & 4.2697 \\
Payroll reconciliation & 4.2870 \\
Payroll record processing & 4.2381 \\
Payroll accounting system coverage & 4.3375 \\
\hline
\end{tabular}

\section{Inferential Results}

\section{Assumptions of Using SEM}

The assumptions of using SEM were tested in order to justify the use of SEM. These assumptions include the normal distribution of data, Multicollinearity, linear relationship and homoscedasticity. Data were found to be normally distributed because the Shapiro Wilks test coefficients in all variables were insignificant ranging from the P-value of 0.156 to 0.241 . Shapiro Wilks test is recommended when the sample size is less than 2000 (Zar, 1999). The Multicollinearity problem was also examined and using Inter-Factor Correlation indicated that there is no such problem. The Inter-factor correlation of coefficients which were less than 0.70 which indicated that the variables were not highly correlated as shown in Appendix 3.

The article had four broad hypotheses that were categorised into three sub-hypotheses each. The first hypothesis $\left(\mathrm{H}_{1}\right)$ stated that control environment positively influences the performance of payroll accounting system. $\mathrm{H}_{1}$ was divided into three sub-hypotheses, $\mathrm{H}_{1 \mathrm{a}}, \mathrm{H}_{1 \mathrm{~b}}$ and $\mathrm{H}_{1 \mathrm{c}}$. $\mathrm{H}_{1 \mathrm{a}}$ stated that control environment positively influences payroll reconciliation while $\mathrm{H}_{1 \mathrm{~b}}$ stated that the control environment positively influences payroll record processing. $\mathrm{H}_{1 \mathrm{c}}$ stated that the control environment positively influences the coverage of payroll accounting system. The results revealed that control environment had insignificant influence on payroll reconciliation. The regression weight was -0.074 but insignificant at 0.542 hence $\mathrm{H}_{1 a}$ was not supported. The results further showed that control environment had significantly positive influence on payroll record processing. The regression weight was 0.388 and significant at 0.019 (less than 0.05). Hence $H_{1 b}$ was supported. It was further revealed that control environment had insignificant influence on the payroll accounting system coverage. The regression weight was -0.142 and insignificant at 0.174 . In this case, $\mathrm{H}_{1 \mathrm{c}}$ was not supported which demonstrated that $\mathrm{H}_{1}$ was partially supported as shown in appendix 4.

$\mathrm{H}_{2}$ stated that internal auditors' professional competence positively influences the performance of payroll accounting system. It was further divided into three sub-hypotheses coded as $\mathrm{H}_{2 \mathrm{a}}, \mathrm{H}_{2 \mathrm{~b}}$ and $\mathrm{H}_{2 \mathrm{c}}$. $\mathrm{H}_{2 \mathrm{a}}$ stated that internal auditors' pro- 
fessional competence positively influences payroll reconciliation while $\mathrm{H}_{2 \mathrm{~b}}$ stated that the internal auditors' professional competence positively influences payroll record processing. $\mathrm{H}_{2 \mathrm{c}}$ stated that the internal auditors' professional competence positively influences the coverage of payroll accounting system. The results revealed that internal auditors' professional competence had significant positive influence on payroll reconciliation, payroll record processing and payroll accounting system coverage. Hence, $\mathrm{H}_{2 \mathrm{a}}, \mathrm{H}_{2 \mathrm{~b}}$ and $\mathrm{H}_{2 \mathrm{c}}$ were supported. The regression weight for $\mathrm{H}_{2 \mathrm{a}}$ was 0.338 , significant at $0.002 ; \mathrm{H}_{2 \mathrm{~b}}$ was 1.297 and significant at 0.001 , while for $\mathrm{H}_{2 \mathrm{c}}$ was 0.482 , significant at 0.001 . In this case, $\mathrm{H}_{2}$ was fully supported as shown in appendix 4 .

$\mathrm{H}_{3}$ stated that risk-based internal audit positively influences the performance of payroll accounting system. It was divided into three sub-hypotheses and coded as $\mathrm{H}_{3 a}, \mathrm{H}_{3 \mathrm{~b}}$ and $\mathrm{H}_{3 \mathrm{c}} . \mathrm{H}_{3 \mathrm{a}}$ stated that risk-based internal audit positively influences payroll reconciliation while $\mathrm{H}_{3 \mathrm{~b}}$ stated that risk-based internal audit positively influences payroll record processing. $\mathrm{H}_{3 c}$ stated that risk-based internal audit positively influences the coverage of payroll accounting system. The results revealed that risk-based internal audit had significantly positive influence on the payroll reconciliation hence, $\mathrm{H}_{3 \mathrm{a}}$ was supported. The regression weights for $\mathrm{H}_{3 \mathrm{a}}$ were 0.352 , significant at 0.001 . On the contrary, it was revealed that risk-based internal audit had no significant influence on payroll record processing and the coverage of payroll accounting system. Hence, $\mathrm{H}_{3 b}$ and $\mathrm{H}_{3 c}$ were not supported. The regression weight for $\mathrm{H}_{3 b}$ was -0.509 , insignificant at 0.184 and that of $\mathrm{H}_{3 c}$ was 0.013 , insignificant at 0.840 . Hence, $\mathrm{H}_{3}$ was partially supported as shown in appendix 4 .

$\mathrm{H}_{4}$ stated that internal audit work performance positively influences the performance of payroll accounting system. It was divided into three sub-hypotheses and coded as $\mathrm{H}_{4 a}, \mathrm{H}_{4 b}$ and $\mathrm{H}_{4 c}$. $\mathrm{H}_{4 a}$ stated that internal audit work performance positively influences payroll reconciliation while $\mathrm{H}_{4 \mathrm{~b}}$ stated that internal audit work performance positively influences payroll record processing. $\mathrm{H}_{4 \mathrm{c}}$ stated that internal audit work performance positively influences the coverage of payroll accounting system. The results revealed that internal audit work performance had significantly positive influence on payroll reconciliation and the coverage of payroll accounting system. Hence, $\mathrm{H}_{4 \mathrm{a}}$ and $\mathrm{H}_{4 c}$ were supported. The regression weight for $\mathrm{H}_{4 a}$ was 0.838 , significant at 0.001 and the regression weight for $\mathrm{H}_{4 c}$ was 0.567 and significant at $0.003 . \mathrm{H}_{4 \mathrm{~b}}$ was not supported because the regression weight was -0.546 but insignificant at 0.070 . Hence, $\mathrm{H}_{4}$ was partially supported as shown in Appendix 4.

Furthermore, the model fit indices also showed that the model fitted the data well. the following indices i.e. (CMIN/df, Goodness of Fit Index (GFI), Adjusted GFI, Comparative Fit Index (CFI) and the Root Mean Square Error Approximation (RMSEA) were calculated. The recommended value for CMIN/df is 5 (Bollen, 1989); and GFI is 0.90 (Byrne, 2010) or value that is approximated to 0.90 (Thadani \& Cheung, 2011). Furthermore, the recommended value for ad- 
justed GFI is 0.80 (Chau \& Hu, 2001) while RMSEA should not be more than 0.08 (Hoe, 2008 cited by Hooper, et al., 2008). The calculated model fit indices were as follows: $\mathrm{CMIN} / \mathrm{df}=2.435$; GFI $=0.914$; $\mathrm{AGFI}=0.865 ; \mathrm{CFI}=0.927$ and RMSEA $=0.078$. The CFI was above the cut off print of 0.90 as it has been suggested by Hair, et al. (2010). Figure 1 is the structural equation model that shows the direct relationship among variable.

\section{Discussion of Findings}

The results revealed that control environment had significant positive influence on payroll record processing only. On the other hand, it had insignificant influence on payroll reconciliation and payroll accounting system coverage. Basing on the influence of control environment on payroll record processing, the results of this article are supported by the findings of prior empirical studies (such as IIA, 2012; Kiabel, 2012; Nwaobia, 2016). However, the findings of this article differed on the influence of control environment on payroll reconciliation and payroll record processing by the payroll accounting system. The difference was resulted by the fact that this article focused on the individual performance indicators of the payroll accounting system.

The results also revealed that internal auditors' professional competence had significant positive influence on payroll reconciliation, payroll record processing and payroll accounting system coverage. Generally, the results revealed that internal auditors' professional competence had significant positive influence on

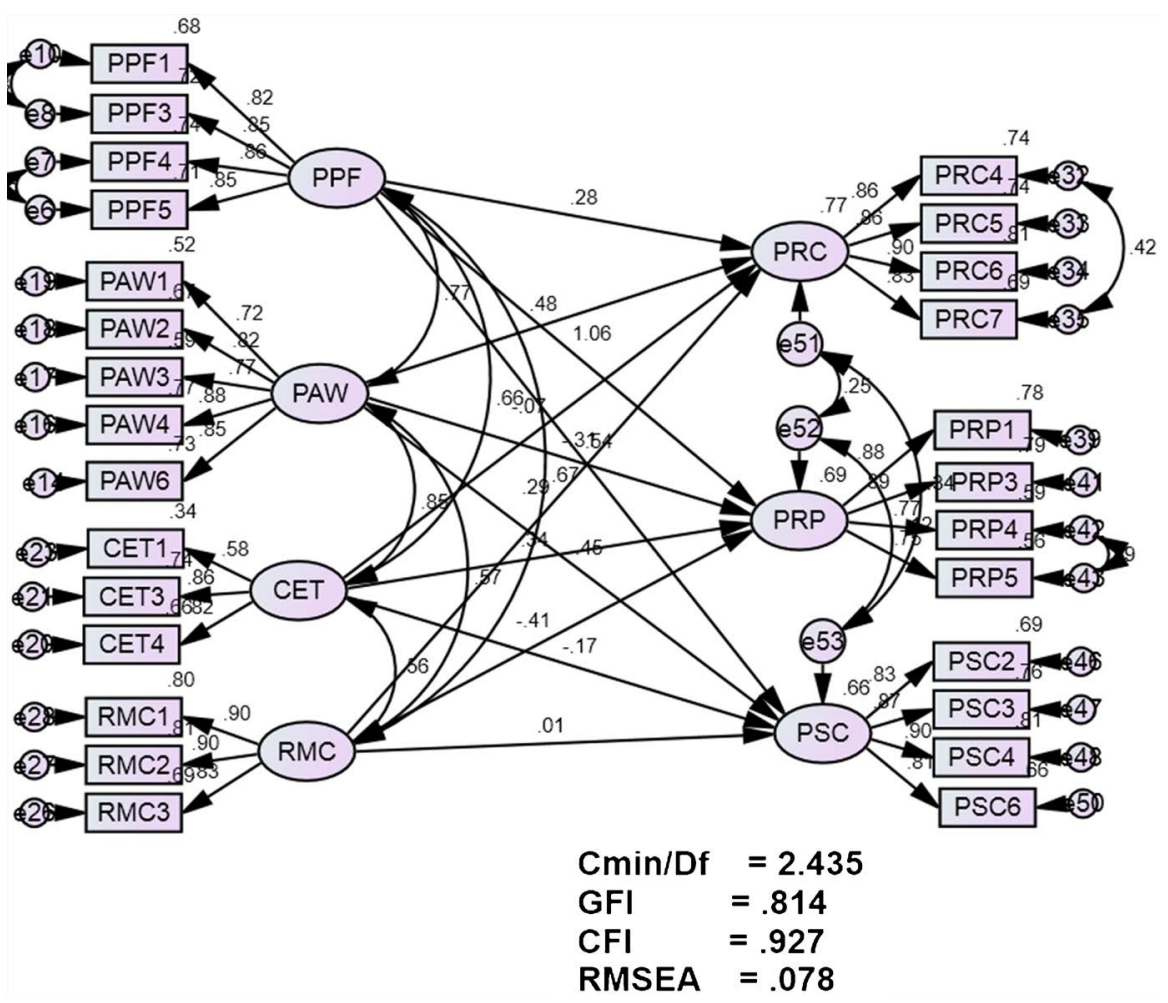

Figure 1. Internal audit practices and payroll accounting system performance. 
payroll accounting system performance. The results of this article are supported by the findings of the prior empirical studies (i.e. IIA, 2009, 2012; Selim et al., 2009).

The results further revealed that risk-based internal audit had significant positive influence on payroll reconciliation and, insignificantly influenced payroll record processing and payroll accounting system coverage. Based on payroll reconciliation, the results of this article are supported by the findings of other empirical studies (i.e. Arena \& Azzona, 2009; Aikins, 2011; Droglas \& Siopi, 2017). However, the results of this article differed with the findings of the mentioned prior empirical studies in the areas of payroll record processing and payroll accounting system coverage. The differences were mainly caused by the focus of this article on the individual performance indicators of the payroll accounting system. Moreover, the results showed that internal auditors' work performance had significant positive influence on payroll reconciliation and payroll system coverage. On the contrary, it had insignificant influence on payroll record processing. Basing on payroll reconciliation and payroll accounting system coverage, the results of this article are supported by other empirical studies (Cohen \& Sayag, 2010; Hellman, 2011).

The descriptive results showed that the public institutions as part of the internal audit practices mainly focus on the auditors' professional competence, control environment, risk-based internal audit and the way or procedures of performing the internal audit. Moreover, the public institutions highly concentrate on payroll reconciliation, payroll record processing and payroll accounting system coverage. Contrary to the descriptive results, the inferential results revealed that control environment, risk-based internal audit practices and internal audit work performance significantly influenced one or two payroll accounting performance indicators. The auditors' professional competence was the only variable that significantly influenced all payroll accounting performance indicators.

The findings of this article revealed that control environment significantly and positively influenced the payroll record processing. This implies that control environmental factors like management support, independence of internal audit unit, availability of required infrastructure facilities, powers of the internal audit unit and stakeholders' support influenced the performance of a payroll system in terms of payroll record processing. Hence, the findings are supported by the Institutional theory which recognises the influence of institutional environment in the performance of an accounting system.

Furthermore, the findings of this article revealed that internal auditors' professional competence significantly and positively influenced on payroll reconciliation, payroll record processing and payroll accounting system coverage. This implies that internal auditors' professional competence had significant positive influence on the performance of payroll accounting system. These findings are supported by the Institutional theory because the internal auditors' professional competence is guided and monitored by the regulatory frameworks and institu- 
tions such as the National Board of Accountants and Auditors (NBAA).

The findings were also in line with the Contingency theory which argues that the contextual factors determine the best way for the organisation to organise itself (Weill \& Olson, 1987). This is in line with the findings of this article which revealed that risk-based internal audit as the contextual factor significantly influenced the payroll reconciliations. Ability of the organisation to prevent both unauthorized access and preparation of fictitious records and, the approval procedures of the payroll transactions enhanced by the risk-based internal audit largely influenced the performance of payroll performance.

Basing on the internal audit work performance, the findings are also supported by the Contingency theory. The findings revealed that internal audit work performance had significant positive influence on payroll reconciliation and payroll system coverage. This implies that the fit between internal audit work performance and the payroll accounting system resulted to the better performance of the payroll accounting system in terms of payroll reconciliation and payroll system coverage.

\section{Conclusion}

The article concludes that control environment significantly and positively influences payroll record processing while internal auditors' professional competence significantly and positively influences payroll reconciliation, payroll record processing and payroll system coverage. It is further concluded that risk-based internal audit has significantly positive influence on payroll reconciliation. The internal audit work performance has significantly positive influence on payroll reconciliation and payroll accounting system coverage.

\section{Research Implications}

Institutional theory has been widely recognised in examining the influence of internal audit practices on the public sector performance that is mainly focusing on the best use of public fund. However, the findings of this article implied that the use of institutional theory alone in examining the influence of internal audit practices on the performance of payroll accounting system is not self-sufficient. The theory mainly builds its arguments on the assumption of homogeneity among the public sector organisation that belongs in the same domain. The findings of this article revealed that there are specific-contextual internal audit practices, such as risk-based internal audit practices and performance of internal audit, that influenced the performance of payroll accounting system in the public sector organisations. With this fact, the article recommends the combination of institutional theory and contingency theory to investigate the influence of internal audit practices on the performance of payroll accounting system.

Managers should not consider internal audit function as an operational function mainly focusing on accounting issues. They must consider it as a strategic function focusing on system audit, performance audit and compliance audit. 
With this fact, managers will fully utilise the potential benefits of the internal audit practices towards enhancing the payroll accounting system performance. This can be achieved by doing the following:

1) Promote the wider participation of managers and ordinary employees in internal audit assignment.

2) Expand the scope of internal audit function depending on the nature and activities of the organisation.

3) Orient internal auditors on organisation operations, goals and plans so that the internal auditing of payroll accounting system will be more than the financial issues.

4) Internal auditors should be widely involved in the preparation of payroll accounting system. Preparation of payroll accounting system should not be considered as the sole responsibility of human resource offices and administrators.

The findings revealed that internal audit practices did not have the same influence on the payroll accounting system performance. Despite the reason presented in this article i.e. the perception of internal audit function by the organisation as an accounting activity, it is important for researchers to have in-depth analysis on the reasons for such different influence on payroll accounting system by internal audit practices. In this case, future studies may focus on the qualitative methods in order to have in-depth analysis of the research phenomenon.

The internal audit practices were found to have different influences on the payroll accounting system performance indicators despite the high focus on both all internal audit practices mentioned in this article and the payroll accounting system performance indicators as shown in the results. However, due to methodological limitation of this article, it was difficult to have in-depth information to explain such a research phenomenon. It is therefore important to conduct the qualitative study to explore why the internal audit practices have different influences on the payroll accounting system performance indicators.

\section{Conflicts of Interest}

The authors declare no conflicts of interest regarding the publication of this paper.

\section{References}

Adegoroye, G. (2008). Public Service Reform for Sustainable Development. The Nigeria Experience. Key Note Address Delivered at the Commonwealth Advanced Seminar, Wellington, 20 March-3 February 2008.

African Development Bank-ADB (2005). African Development Report 2005: Public Sector Management in Africa. Oxford/New York: African Development Bank.

Agwanda, B (2019). Public Sector Reforms and Contemporary Reform Challenges to Sustainable Development in Africa. International Journal of Economics, Business and Politics, 3, 271-288. https://doi.org/10.29216/ueip.607934 
Aikins, S. K. (2011). An Examination of Government Internal Audit's Role in Improving Financial Performance. Public Finance and Management, 11, 306-337.

Akinbuli, S. (2010). The Effect of Audit Expectation Gap on the Work of Auditors, the Profession and Users of Financial Information. Nigerian Accountant Journal, 43, 37-47.

Al-Matari, E. M., Al-Swidi, A. K., \& Fadzil, F. H. (2013). The Effect of the Internal Audit and Firm Performance: A Proposed Research Framework. International Review of Management and Marketing, 4, 34-41.

Al-Shbail, A. M., \& Turki, T. A. A. (2017). A Theoretical Journal of Academic Research in Accounting, Finance and Management Sciences, 7, 107-116. https://doi.org/10.6007/IJARAFMS/v7-i1/2577

Alzeban, A., \& Gwilliam, D. (2012). Perceptions of Managers and Internal Auditors as to Factors Affecting the Effectiveness of Internal Audit in the Public Sector Context. The 10th European Academic Conference on Internal Audit and Corporate Governance, $1-54$.

Arena, M., \& Azzone, G. (2009). Identifying Organizational Drivers of Internal Audit Effectiveness. International Journal of Auditing, 13, 43-60. https://doi.org/10.1111/j.1099-1123.2008.00392.x

Awan, A. G., \& Khan, F. U. (2016). Impact of Management Information System on the Performance of the Organisation (Profitability, Innovation and Growth). Journal of Poverty, Investment and Development, 21, 1-8.

Bollen, K. A. (1989). Structural Equations with Latent Variables. New York: John Wiley \& Sons, Inc. https://doi.org/10.1002/9781118619179

Byrne, B. M. (2012). Structural Equation Modeling with Mplus: Basic Concepts, Applications and Programming. New York: Routledge. https://doi.org/10.4324/9780203807644

Carpenter, V. L., \& Feroz, E. H. (2001). Institutional Theory and Accounting Rule Choice: An Analysis of Four US State Governments' Decisions to Adopt Accounting Principles. Accounting, Organisations and Society, 26, 565-596.

https://doi.org/10.1016/S0361-3682(00)00038-6

Chartered Institute of Management Accountants-CIMA (2010). New Public Sector Performance; Making Fiscal Consolidation Smarter. Unpublished Discussion Paper.

Chau, P. Y. K., \& Hu, P. J. H. (2001). Information Technology Acceptance by Individual Professional: A Model Comparison Approach. Decision Sciences, 32, 699-719. https://doi.org/10.1111/j.1540-5915.2001.tb00978.x

Cohen, A., \& Sayag, G. (2010). The Effectiveness of Internal Auditing: An Empirical Examination of its Determinants in Israeli Organizations. Australian Accounting Review, 20, 296-307. https://doi.org/10.1111/j.1835-2561.2010.00092.x

Diamond, J. M. (2002). The Role of Internal Audit in Government Financial Management. An International Perspective. IMF Working Paper WP/02/94. https://doi.org/10.5089/9781451851731.001

DiMaggio, P. J., \& Powell, W. W. (1983). The Iron Cage Revisited: Institutional Isomorphism and Collective Rationality in Organisational Fields. American Sociological, 48, 147-160. https://doi.org/10.2307/2095101

Doherty, T. L., \& Horne, T. (2002). Managing the Public Services: Implementing Changes. A Thoughtful Approach. London: Routledge

Dorotinsky, W., \& Pradhan (2007). Corruption and the Public Financial Management System in the Many Faces of Corruption: Tracking Vulnerabilities at the Sector Level. In J. Edgardo, \& S. Pradhan (Eds.), Washington, DC, World Bank. 
Drogalas, G., \& Siopi, S. (2017). Risk Management and Internal Audit: Evidence from Greece. Risk Governance and Control: Financial Markets and Institutions, 7, 104-110. https://doi.org/10.22495/rgcv7i3p10

Fatile, J, Olufemi, A., \& Kehinde, D. (2010) Public Sector Reform in Africa: Issues, Lessons and Future Directions. Journal of Sustainable Development in Africa, 12.

Fatile, J. O. (2012). Electronic Governance: Myth or Opportunity for Nigerian Public Administration? International Journal of Academic Research in Business and Social Sciences, 2, 122-140.

Feizizadeh, A. (2012). Strengthening Internal Audit Effectiveness. Indian Journal of Science and Technology, 5, 2777-2778. https://doi.org/10.17485/ijst/2012/v5i5.18

Fiszbein, A. (2000). Public-Private Partnerships as a Strategy for Local Capacity Building: Some Suggestive Evidence from Latin America. In P. Collins (Ed.), Applying Public Administration in Development: Guideposts to the Future (1029-1043). Chichester: Wiley.

Hair, J. F., Black, W. C., Babin, B. J., \& Anderson, R. E. (2010). Multivariate Data Analysis (7th ed.). Upper Saddle River, NJ: Prentice Hall.

Hellman, N. (2011). Chief Financial Officer Influence on Audit Planning. International Journal of Auditing, 15, 247-274. https://doi.org/10.1111/j.1099-1123.2011.00433.x

Hepworth, N. (2004). Is the Modern Risk Based Approach to Public Sector Internal Audit Really Appropriate for Countries with Less Developed Systems and Less Well Trained Public Officials? London: CIPFA.

http://www.cipfa.org.uk/international/download/paper_internalaudit hepworth octo4 $\underline{\text { Doc }}$

Hoe, S. L. (2008). Issues and Procedure in Adopting Structural Equation Modeling Technique. Journal of Applied Quantitative Methods, 3, 76-83.

Hooper, D., Coughlan, J., \& Mullen, M. (2008). Structural Equation Modeling: Guidelines for Determining Model Fit. Electronic Journal of Business Research Methods, 6, 53-60.

Hutchinson, M. R., \& Zain, M. M. (2009). Internal Audit Quality, Audit Committee Independence, Growth Opportunities and Firm Performance. Corporate Ownership and Control, 7, 50-63. https://doi.org/10.22495/cocv7i2p4

Institute of Internal Auditors (IIA) (2009). The Role of Auditing in Public Sector Governance. Altamonte Springs, FL: The Institute of Internal Auditors Research Foundation.

Institute of Internal Auditors (IIA) (2012). Supplemental Guidance: The Role of Auditing in Public Sector Governance (2nd ed.).

https://global.theiia.org/standards-guidance/Pages/Standards-and-Guidance-IPPF.aspx

International Federation of Accountants (IFAC) (2010). IFAC Handbook of International Public Sector Accounting Pronouncements (2010 ed.). IFAC Publications, 2, 1-10.

Kaiser, K., \& Bostrom, R. (1982). Personality Characteristics of MIS Project Teams: An Empirical Study and Action Research Design. MIS Quarterly, 6, 43-60. https://doi.org/10.2307/249066

Kiabel, B. D. (2012). International Auditing and Performance of Government Enterprises: A Nigerian Study. Global Journal of Management and Business Research, 12, 5-20.

Lufunyo, H. (2013). Impact of Public Sector Reforms on Service Delivery in Tanzania. International Journal of Social Science Tomorrow, 5, 26-49.

https://www.tanzania.go.tz/egov uploads/documents/PSRP Service delivery sw.pdf https://doi.org/10.5897/JPAPR12.014

Martinez, \& Dacin, M. T. (1999). Efficiency Motives and Normative Forces: Combining 
Transactions Costs and Institutional Logic. Journal of Management, 25, 75-96. https://doi.org/10.1177/014920639902500104

Mihret, D. G., James, K., \& Mula, J. M. (2010). Antecedents and Organisation Performance Implications of Internal Audit Effectiveness: Some Propositions and Research Agenda. Pacific Accounting Review, 22, 224-252. https://doi.org/10.1108/01140581011091684

Muchiri, N. W., \& Jagongo, A. (2017). International Auditing and Financial Performance of Public Institutions in Kenya: A Case of Kenya Meat Commission. African Journal of Business Management, 11, 168-174. https://doi.org/10.5897/AJBM2017.8267

Nunnaly, J. C. (1967). Psychometric Theory. New York: McGraw-Hill.

Nwaobia, A. N., Ogundajo, G. O., \& Niyonzima, T. (2006). Internal Audit Practices and Public Financial Management in Rwanda and Nigeria: Bridging the Transparency Gap in Public Sector Reporting. International Journal of Advanced Academic Research [Social and Management Sciences], 2, 59-77.

Nzuve, S., \& Njeru, L. (2013). Perceived Factors Affecting Performance Management among Local Authorities in Kenya: A Case of the City Council of Nairobi. DBA Africa Management Review, 3, 59-69.

Obara, L., \& Nangih, E. (2017). Accounting System and Payroll Fraud in the Public Sector: A Survey of Selected Ministries and Parastatals in River State, Nigeria. Journal of Accounting and Financial Management, 3, 10-24.

Okezie, B. N. (2004). Auditing and Investigations. Owerri: Bon Publications.

Oliver, C. (1997). Sustainable Competitive Advantage: Combining Institutional and Resource-Based Views. Strategic Management Journal, 18, 697-713. https://doi.org/10.1002/(SICI)1097-0266(199710)18:9<697::AID-SMJ909>3.0.CO;2-C

Polidano, C (2001). Why Civil Service Reform Fail. Public Management Review, 3, 345-361. https://doi.org/10.1080/14616670110050039

Rameesh, K (2003) Best Practices for Internal Audit in Government Departments. http://www.cgg.gov.in/pdfs/WP-10-Rameesh\%20Kailasam.pdf

Rugumyamheto, J. (2005). Reforming the Public Service in Tanzania: A Critical Prerequisite to Economic Growth, Wealth Creation and Poverty Reduction. The 26th African Association for Public Administration and Management Annual Roundtable Conference, Mombasa, March 2005, 32-47.

Sage (2011). 15 Factors to Consider When Changing How You Process Payroll. Sage HRMS I Planning Guide. http://www.sagehrms.com/

Scott, W. R. (1987). The Adolescence of Institutional Theory. Administrative Science Quarterly, 32, 493-511. https://doi.org/10.2307/2392880

Scott, W. R. (1987). The Adolescence of Institutional Theory. Administrative Science Quarterly, 32, 493-511. http://www.jstor.org/page/info/about/policies/terms.jsp https://doi.org/10.2307/2392880

Selim, G., Woodward, S., \& Allegrini, M. (2009). Internal Auditing and Consulting Practice: A Comparison between UK/Ireland and Italy. International Journal of Auditing, 13, 9-25. https://doi.org/10.1111/j.1099-1123.2008.00395.x

Suryanto, S. (2011). Design and Analysis: Payroll of Accounting Information System. CommIT (Communication and Information, 5, 24-26. https://doi.org/10.21512/commit.v5i1.555

Thadani, D. R., \& Cheung, C. M. K. (2011). Online Social Network Dependency: Theoretical Development and Testing of Competing Models. 44th Hawaii International 
Conference On System Sciences, Kauai, 4-7 January 2011, 1-9.

https://doi.org/10.1109/HICSS.2011.331

Therkildsen, O. (2000). Public Sector Reform in a Poor, Aid-Dependent Country, Tanzania. Public Administration and Development, 20, 61-71. https://doi.org/10.1002/1099-162X(200002)20:1<61::AID-PAD101>3.0.CO;2-T

Thisted, R. A. (2006). The Cross-Sectional Study: Investigating Prevalence and Association. Chicago, IL: The University of Chicago.

Toakodi, A., \& Assi, V. (2016). Corruption in the Civil Service: A Study of Payroll Fraud in Selected Ministries, Departments and Agencies (MDAs) in Bayelsa State, Nigeria. Research on Humanities and Social Sciences, 6, 53-69.

Tsai, W., Chen, H., Chang, J., \& Lee, H. (2017). The Internal Audit Performance: The Effectiveness of ERM and IT Environment. Proceedings of the 50th Hawaii International Conference on System Sciences, Hilton Waikoloa Village, Hawaii, 4-7 January 2017, 4898-4906. https://doi.org/10.24251/HICSS.2017.595

Van Gansberghe, C. N. (2005). Internal Audit. Finding its Place in Public Finance Management. Washington, DC: International Bank for Reconstruction and Development/The World Bank.

Vijayakumar, A., \& Nagaraja, N. (2012). Internal Control Systems: Effectiveness of Internal Audit in Risk Management at Public Sector Enterprises. BVIMR Manage. Edge 5, 1-8.

Weill, P., \& Oslon, M. (1987). An Assessment of the Contingency Theory of MIS. The Working Paper Series No. IS-87-31, New York: The Center for Digital Economy Research.

Weiss, M. (1983). Effects of Work Stress and Social Support on MIS Managers. MIS Quarterly, 7, 29-43. https://doi.org/10.2307/249075

Young, O. R. (1982) Resource Regimes. Natural Resources and Social Institutions. Berkley: University of California Press. https://doi.org/10.1525/9780520315457

Zar, J. H. (1999). Biostatistical Analysis (4th ed.). Upper Saddle River, NJ: Prentice-Hall. 


\section{Appendix 1. Exploratory Factor Analysis for Internal Audit Practices}

\begin{tabular}{|c|c|c|c|c|c|}
\hline \multirow{2}{*}{ Variable } & \multirow{2}{*}{ Item } & \multicolumn{4}{|c|}{ Component } \\
\hline & & 1 & 2 & 3 & 4 \\
\hline \multirow{10}{*}{$\begin{array}{l}\text { Internal } \\
\text { Auditors' } \\
\text { Professional } \\
\text { Competence }\end{array}$} & Management ensures staff understands their accountabilities. & 0.842 & & & \\
\hline & Management ensures staff understands their duties & 0.802 & & & \\
\hline & Management ensures staff understands their responsibilities. & 0.791 & & & \\
\hline & $\begin{array}{l}\text { Management has to confirm if reports that provide the details of the payroll amounts charged to the } \\
\text { department's accounts are compared to the approved copy by someone who did not prepare the } \\
\text { both reports. }\end{array}$ & 0.766 & & & \\
\hline & Management confirms reconciliation is performed by someone/unit outside of the payroll function & 0.763 & & & \\
\hline & $\begin{array}{c}\text { Management has to confirm if reports that provide the details of the payroll amounts charged to the } \\
\text { department's accounts are reviewed to the approved copy by someone who did not prepare the both } \\
\text { reports. }\end{array}$ & 0.734 & & & \\
\hline & $\begin{array}{l}\text { Management confirms access to the master payroll file or payroll production database is limited to } \\
\text { employees authorized to make changes }\end{array}$ & 0.626 & & & \\
\hline & Payroll records are protected from destruction & 0.615 & & & \\
\hline & Management confirms logical access to payroll applications controlled by passwords. & 0.605 & & & \\
\hline & Payroll expenditures reviewed by an authorized signatory prior to the payroll cycle. & 0.592 & & & \\
\hline \multirow{10}{*}{$\begin{array}{l}\text { Control } \\
\text { Environment }\end{array}$} & Auditors confirm the accuracy of the changes like salary increment made in the system & & 0.685 & & \\
\hline & $\begin{array}{l}\text { Auditors confirm whether reconciliation between actual salary payments to the Ministry's/LG's } \\
\text { supporting schedule was done }\end{array}$ & & 0.682 & & \\
\hline & Auditors confirm proof of qualifications of the employees by inspection of the system personnel files & & 0.665 & & \\
\hline & Auditors confirm the accuracy of the changes like removal of the retirees in the system & & 0.622 & & \\
\hline & $\begin{array}{l}\text { Auditors confirm invalid changes like salary increment by making comparison between salary data } \\
\text { sheet and the system }\end{array}$ & & 0.594 & & \\
\hline & Auditors confirm the validity of appointment of the new employees by inspection of personnel files. & & 0.587 & & \\
\hline & $\begin{array}{l}\text { Auditors confirm invalid changes like salary scale by making comparison between salary data sheet } \\
\text { and the system }\end{array}$ & & 0.581 & & \\
\hline & $\begin{array}{l}\text { During strategic planning, auditors have to plan their work in such a manner that any material } \\
\text { misstatements in the financial statements can be identified. }\end{array}$ & & 0.571 & & \\
\hline & $\begin{array}{l}\text { Auditors confirm that the funds allocated for personnel by the ministry of Finance agree to } \\
\text { supporting schedules. }\end{array}$ & & 0.558 & & \\
\hline & Auditors investigate significant differences on the amount spent to previous months to the current. & & 0.507 & & \\
\hline \multirow{5}{*}{$\begin{array}{l}\text { Risk-based } \\
\text { Internal } \\
\text { Audit }\end{array}$} & Personnel records are safeguarded to prevent unauthorized access & & & 0.788 & \\
\hline & Personnel records are safeguarded to prevent the preparation of fictitious records & & & 0.779 & \\
\hline & The amount of salary for each of the employee are approved by the management & & & 0.641 & \\
\hline & $\begin{array}{l}\text { Management ensures that changes to the payroll file or database is approved by someone other than } \\
\text { the person making the change. }\end{array}$ & & & 0.631 & \\
\hline & Payroll records are protected from theft & & & 0.546 & \\
\hline
\end{tabular}




\section{Continued}

Auditors are aware of the payroll accounting system

Internal Audit The audit assignment starts with the issuance of the engagement letter by the auditor to the client's

Work

management.

Performance

During strategic planning the auditors have to understand the entity.

During strategic planning, the auditors have to identify risk areas

Extraction Method: Principal Component Analysis. Rotation Method: Varimax with Kaiser Normalization. a. Rotation converged in 13 iterations.

Appendix 2. Exploratory Factor Analysis for Payroll Accounting System Performance

\begin{tabular}{|c|c|c|c|c|}
\hline \multirow{2}{*}{ Variable } & \multirow{2}{*}{ Item } & \multicolumn{3}{|c|}{ Component } \\
\hline & & 1 & 2 & 3 \\
\hline \multirow{10}{*}{$\begin{array}{c}\text { Payroll } \\
\text { Reconciliation }\end{array}$} & $\begin{array}{l}\text { Annual reconciliation of gross pay amounts as shown on tax returns to total payroll on the general ledger } \\
\text { has led to the effectiveness of payroll accounting system }\end{array}$ & 0.946 & & \\
\hline & Payroll system has reduced the scenario of employees having more than one check number & 0.889 & & \\
\hline & $\begin{array}{l}\text { Quarterly reconciliation of gross pay amounts as shown on tax returns to total payroll on the payroll register } \\
\text { has led to the effectiveness of payroll accounting system. }\end{array}$ & 0.874 & & \\
\hline & Payroll accounting system has reduced the number of ghost employees at work places & 0.871 & & \\
\hline & $\begin{array}{l}\text { Annual reconciliation of gross pay amounts as shown on tax returns to total payroll on the payroll register } \\
\text { has led to the effectiveness of payroll accounting system. }\end{array}$ & 0.862 & & \\
\hline & $\begin{array}{l}\text { Monthly reconciliation of gross pay amounts as shown on tax returns to total payroll on the general ledger } \\
\text { has led to the effectiveness of payroll accounting system. }\end{array}$ & 0.847 & & \\
\hline & $\begin{array}{l}\text { Payroll system has reduced the scenario of retired employees(leaver) to continue receiving their salaries } \\
\text { because of late removal from the next payroll run }\end{array}$ & 0.840 & & \\
\hline & $\begin{array}{l}\text { Quarterly reconciliation of gross pay amounts as shown on tax returns to total payroll on the general ledger } \\
\text { has led to the effectiveness of payroll accounting system. }\end{array}$ & 0.818 & & \\
\hline & $\begin{array}{l}\text { Monthly reconciliation of gross pay amounts as shown on tax returns to total payroll on the payroll register } \\
\text { has led to the effectiveness of payroll accounting system. }\end{array}$ & 0.795 & & \\
\hline & $\begin{array}{l}\text { Regular reconciliation between payroll accounting system and personnel system has led to the effectiveness } \\
\text { of payroll system. }\end{array}$ & 0.757 & & \\
\hline \multirow{6}{*}{$\begin{array}{l}\text { Payroll Record } \\
\text { Processing }\end{array}$} & Detailed pay histories available to management & & 0.823 & \\
\hline & Accurate pay histories available to employees & & 0.797 & \\
\hline & Payroll accounting system produces all appropriate reports which are relevant for decision making & & 0.784 & \\
\hline & With technology employees are paid on time & & 0.639 & \\
\hline & With technology payroll is processed accurately & & 0.628 & \\
\hline & Detailed pay histories available to employees & & 0.563 & \\
\hline \multirow{6}{*}{$\begin{array}{c}\text { Payroll } \\
\text { Accounting } \\
\text { System } \\
\text { Coverage }\end{array}$} & Lawson system is able to cover possible scenarios like terminated employees & & & 0.812 \\
\hline & Lawson system is able to cover possible scenarios like staff near to retirement & & & 0.755 \\
\hline & Lawson system is able to cover possible scenarios like demotion & & & 0.738 \\
\hline & Lawson system is able to cover possible scenarios like promotion & & & 0.701 \\
\hline & Lawson system is able to cover possible scenarios like retired staff & & & 0.653 \\
\hline & The system is able to cover possible scenarios which prevailed in the payroll like promotion or demotion & & & 0.579 \\
\hline
\end{tabular}

Extraction Method: Principal Component Analysis. Rotation Method: Oblimin with Kaiser Normalization. a. Rotation converged in 16 iterations. 


\section{Appendix 3. Correlation of Coefficients}

\begin{tabular}{|c|c|c|c|c|c|c|c|c|}
\hline & & $\begin{array}{c}\text { Internal } \\
\text { Auditors' } \\
\text { Professional } \\
\text { Competence }\end{array}$ & $\begin{array}{c}\text { Control } \\
\text { Environment }\end{array}$ & $\begin{array}{c}\text { Risk based } \\
\text { Internal } \\
\text { Audit }\end{array}$ & $\begin{array}{l}\text { Internal Audit } \\
\text { Work } \\
\text { Performance }\end{array}$ & $\begin{array}{l}\text { Payroll } \\
\text { reconciliation }\end{array}$ & $\begin{array}{c}\text { Payroll } \\
\text { Records } \\
\text { Processing }\end{array}$ & $\begin{array}{c}\text { Payroll } \\
\text { Accounting } \\
\text { System } \\
\text { Coverage }\end{array}$ \\
\hline Internal Auditors' & Pearson Correlation & 1 & $0.639^{\star *}$ & $0.561^{* *}$ & $0.650^{* *}$ & $0.493^{* *}$ & $0.554^{* *}$ & $0.633^{* *}$ \\
\hline \multirow{2}{*}{$\begin{array}{l}\text { Professional } \\
\text { Competence }\end{array}$} & Sig. (2-tailed) & & 0.000 & 0.000 & 0.000 & 0.000 & 0.000 & 0.000 \\
\hline & $\mathrm{N}$ & 240 & 240 & 240 & 240 & 240 & 240 & 240 \\
\hline \multirow{3}{*}{$\begin{array}{c}\text { Control } \\
\text { Environment }\end{array}$} & Pearson Correlation & $0.639^{* *}$ & 1 & $0.616^{* *}$ & $0.587^{* *}$ & $0.534^{* *}$ & $0.305^{\star *}$ & $0.660^{* *}$ \\
\hline & Sig. (2-tailed) & 0.000 & & 0.000 & 0.000 & 0.000 & 0.000 & 0.000 \\
\hline & $\mathrm{N}$ & 240 & 240 & 240 & 240 & 240 & 240 & 240 \\
\hline \multirow{3}{*}{$\begin{array}{l}\text { Risk-based } \\
\text { Internal Audit }\end{array}$} & Pearson Correlation & $0.561^{\star *}$ & $0.616^{\star *}$ & 1 & $0.607^{\star \star}$ & $0.423^{* \star}$ & $0.326^{\star *}$ & $0.574^{\star *}$ \\
\hline & Sig. (2-tailed) & 0.000 & 0.000 & & 0.000 & 0.000 & 0.000 & 0.000 \\
\hline & $\mathrm{N}$ & 240 & 240 & 240 & 240 & 240 & 240 & 240 \\
\hline \multirow{3}{*}{$\begin{array}{c}\text { Internal Audit } \\
\text { Work Performance }\end{array}$} & Pearson Correlation & $0.650^{* *}$ & $0.587^{\star *}$ & $0.607^{\star *}$ & 1 & $0.646^{* *}$ & $0.288^{* *}$ & $0.565^{\star *}$ \\
\hline & Sig. (2-tailed) & 0.000 & 0.000 & 0.000 & & 0.000 & 0.000 & 0.000 \\
\hline & $\mathrm{N}$ & 240 & 240 & 240 & 240 & 240 & 240 & 240 \\
\hline \multirow{3}{*}{$\begin{array}{c}\text { Payroll } \\
\text { reconciliation }\end{array}$} & Pearson Correlation & $0.493^{* *}$ & $0.534^{* *}$ & $0.423^{* *}$ & $0.646^{* *}$ & 1 & $0.466^{* *}$ & $0.643^{* *}$ \\
\hline & Sig. (2-tailed) & 0.000 & 0.000 & 0.000 & 0.000 & & 0.000 & 0.000 \\
\hline & $\mathrm{N}$ & 240 & 240 & 240 & 240 & 240 & 240 & 240 \\
\hline \multirow{3}{*}{$\begin{array}{l}\text { Payroll Records } \\
\text { Processing }\end{array}$} & Pearson Correlation & $0.554^{* *}$ & $0.305^{* *}$ & $0.326^{* *}$ & $0.288^{* *}$ & $0.466^{* *}$ & 1 & $0.439^{* *}$ \\
\hline & Sig. (2-tailed) & 0.000 & 0.000 & 0.000 & 0.000 & 0.000 & & 0.000 \\
\hline & $\mathrm{N}$ & 240 & 240 & 240 & 240 & 240 & 240 & 240 \\
\hline \multirow{3}{*}{$\begin{array}{l}\text { Payroll Accounting } \\
\text { System Coverage }\end{array}$} & Pearson Correlation & $0.633^{* *}$ & $0.660^{* *}$ & $0.574^{* *}$ & $0.565^{\star *}$ & $0.643^{* \star}$ & $0.439^{* *}$ & 1 \\
\hline & Sig. (2-tailed) & 0.000 & 0.000 & 0.000 & 0.000 & 0.000 & 0.000 & \\
\hline & $\mathrm{N}$ & 240 & 240 & 240 & 240 & 240 & 240 & 240 \\
\hline
\end{tabular}

**. Correlation is significant at the 0.01 level (2-tailed).

\section{Appendix 4. Regression Weights: (Group Number 1 Default Model)}

\begin{tabular}{|c|c|c|c|c|c|c|c|}
\hline \multicolumn{3}{|c|}{ Relationship } & \multirow{2}{*}{$\begin{array}{c}\text { Estimate } \\
0.338\end{array}$} & \multirow{2}{*}{$\begin{array}{l}\text { S.E. } \\
0.109\end{array}$} & \multirow{2}{*}{$\begin{array}{c}\text { C.R. } \\
3.087\end{array}$} & \multirow{2}{*}{$\begin{array}{c}\mathbf{P} \\
0.002\end{array}$} & \multirow[t]{2}{*}{ Label } \\
\hline PRC & $<---$ & PPF & & & & & \\
\hline PRP & $<---$ & PPF & 1.297 & 0.171 & 7.563 & $* * *$ & \\
\hline PSC & $<---$ & PPF & 0.482 & 0.098 & 4.943 & $* * *$ & \\
\hline PRC & $<---$ & PAW & 0.838 & 0.224 & 3.733 & $* * *$ & \\
\hline PSC & $<---$ & CET & -0.142 & 0.105 & -1.36 & 0.174 & \\
\hline PRC & $<---$ & $\mathrm{RMC}$ & 0.352 & 0.077 & 4.553 & $* * *$ & \\
\hline PRP & $<---$ & $\mathrm{RMC}$ & -0.509 & 0.106 & -4.782 & $* * *$ & \\
\hline PRP & $<---$ & CET & 0.388 & 0.166 & 2.345 & 0.019 & \\
\hline
\end{tabular}




\section{Continued}

\begin{tabular}{|c|c|c|c|c|c|c|}
\hline PRC & $<---$ & CET & -0.074 & 0.122 & -0.609 & 0.542 \\
\hline PRP & $<---$ & PAW & -0.546 & 0.302 & -1.809 & 0.07 \\
\hline PSC & $<---$ & PAW & 0.567 & 0.189 & 3 & 0.003 \\
\hline PSC & $<---$ & $\mathrm{RMC}$ & 0.013 & 0.065 & 0.202 & 0.84 \\
\hline PPF5 & $<---$ & PPF & 1.139 & 0.075 & 15.173 & $* * *$ \\
\hline PPF4 & $<---$ & PPF & 1.139 & 0.073 & 15.527 & $* * *$ \\
\hline PPF3 & $<---$ & PPF & 1.033 & 0.047 & 21.762 & $* * *$ \\
\hline PPF1 & $<---$ & PPF & 1 & & & \\
\hline PAW6 & $<---$ & PAW & 1.436 & 0.111 & 12.94 & $* * *$ \\
\hline PAW4 & $<---$ & PAW & 1.43 & 0.108 & 13.305 & $* * *$ \\
\hline PAW3 & $<---$ & PAW & 1.156 & 0.1 & 11.581 & $* * *$ \\
\hline PAW2 & $<---$ & PAW & 1.381 & 0.111 & 12.4 & $* * *$ \\
\hline PAW1 & $<---$ & PAW & 1 & & & \\
\hline CET4 & $<---$ & CET & 1 & & & \\
\hline CET3 & $<---$ & CET & 0.853 & 0.06 & 14.293 & $* * *$ \\
\hline CET1 & $<---$ & CET & 0.712 & 0.079 & 9.045 & $* * *$ \\
\hline RMC3 & $<---$ & $\mathrm{RMC}$ & 1.115 & 0.065 & 17.137 & $* * *$ \\
\hline RMC2 & $<---$ & RMC & 1.076 & 0.055 & 19.598 & $* * *$ \\
\hline RMC1 & $<---$ & RMC & 1 & & & \\
\hline PRC4 & $<---$ & PRC & 1 & & & \\
\hline PRC5 & $<---$ & PRC & 0.868 & 0.05 & 17.339 & $* * *$ \\
\hline PRC6 & $<---$ & PRC & 0.906 & 0.048 & 18.785 & $* * *$ \\
\hline PRC7 & $<---$ & PRC & 0.893 & 0.041 & 21.672 & $* * *$ \\
\hline PRP1 & $<---$ & PRP & 1 & & & \\
\hline PRP3 & $<---$ & PRP & 0.924 & 0.051 & 18.27 & $* * *$ \\
\hline PRP4 & $<---$ & PRP & 0.714 & 0.05 & 14.381 & $* * *$ \\
\hline PRP5 & $<---$ & PRP & 0.67 & 0.049 & 13.724 & $* * *$ \\
\hline PSC2 & $<---$ & PSC & 1 & & & \\
\hline PSC3 & $<---$ & PSC & 1.303 & 0.078 & 16.779 & $* * *$ \\
\hline PSC4 & $<---$ & PSC & 1.187 & 0.068 & 17.543 & $* * *$ \\
\hline PSC6 & $<---$ & PSC & 1.217 & 0.081 & 14.981 & $* * *$ \\
\hline
\end{tabular}

